\title{
Antimicrobial resistance profiles and molecular characterization of Escherichia coli strains isolated from healthy adults in Ho Chi Minh City, Vietnam
}

\author{
Phuong Hoai HOANG ${ }^{1,2)}$, Sharda Prasad AWASTHI ${ }^{1)}$, Phuc DO NGUYEN ${ }^{2)}$, \\ Ngan Ly Hoang NGUYEN ${ }^{2)}$, Dao Thi Anh NGUYEN ${ }^{2)}$, Ninh Hoang LE ${ }^{2)}$, \\ Chinh VAN DANG ${ }^{2)}$, Atsushi HINENOYA ${ }^{1)}$ and Shinji YAMASAKI ${ }^{1)^{*}}$ \\ ${ }^{1)}$ Graduate School of Life and Environmental Sciences, Osaka Prefecture University, Osaka 598-8531, Japan
${ }^{2)}$ Institute of Public Health, Ho Chi Minh, Vietnam
}

J. Vet. Med. Sci.

79(3): 479-485, 2017

doi: 10.1292/jvms.16-0639

Received: 19 December 2016 Accepted: 9 January 2017 Published online in J-STAGE: 26 January 2017

\begin{abstract}
In this study, we attempted to isolate Escherichia coli from healthy adults in Ho Chi Minh City, Vietnam, and characterized its antimicrobial resistance profile, extended-spectrum $\beta$-lactamase (ESBL) genotype, phylogenetic grouping and virulence gene profile. A total of $103 \mathrm{E}$. coli isolates were obtained, and most of them were antimicrobial resistant such to streptomycin (80.6\%), tetracycline (67.0\%), ampicillin (65.0\%), sulfamethoxsazole/trimethoprim $(48.5 \%)$, nalidixic acid $(43.7 \%)$, chloramphenicol $(34.0 \%)$, cefotaxime $(15.5 \%)$, ciprofloxacin $(15.5 \%)$, kanamycin (12.6\%), ceftazidime (10.7\%), fosfomycin (4.9\%) and gentamicin (2.9\%). However, all these E. coli strains were susceptible to imipenem. Surprisingly, of 103 strains, $74(71.8 \%)$ and $43(41.7 \%)$ strains showed resistance to more than 3 and 5 classes of antimicrobials, respectively. Furthermore, $10 \mathrm{E}$. coli strains were ESBL-producers and positive for bla $a_{\mathrm{CTX}-\mathrm{M}}$ genes $\left(7\right.$ for $b l a_{\mathrm{CTX}-\mathrm{M}-9}$ and 3 for $\left.b / a_{\mathrm{CTX}-\mathrm{M}-1}\right)$, while five were additionally positive for $b / a_{\mathrm{TEM}}$ genes. $\mathrm{S} 1$-nuclease pulsed-field gel electrophoresis analysis revealed that 7 and 3 strains of $E$. coli carry bla $a_{\mathrm{CTX}-\mathrm{M}}$ genes on their large plasmid and chromosome, respectively. Phylogenetic analysis exhibited that majority of the $E$. coli strains was grouped into A (44.7\%), followed by B1 (23.3\%), B2 (18.4\%) and D (13.6\%). Virulence genes associated with diarrheagenic $E$. coli, such as astA, EAF, eaeA, elt and eagg were also detected in ESBL-producing E. coli as well as antimicrobial resistant strains. These data suggest that commensal $E$. coli of healthy human could be a reservoir for antimicrobial resistance determinants and some of them might be harmful to human.
\end{abstract}

KEY WORDS: E. coli, ESBL, healthy individual, virulence gene

Antimicrobial agents have contributed not only in human medicine but also in veterinary medicine and animal-originated food productions. On the other hand, emergence and dissemination of antimicrobial resistant bacteria, particularly multidrug resistance (MDR), has become a serious global concern [20,35].

Escherichia coli are commensal bacteria in the gut of warm-blooded animals including human and constitute a part of the normal flora $[13,18]$. However, some of them can cause diseases in human and animals, such as intestinal and extra-intestinal infections $[13,18]$, including diarrhea, urinary tract infection, meningitis, septicemia and so on. Resistance to antimicrobial agents of both pathogenic and nonpathogenic E. coli strains from human, animal and food origin has been reported [37]. Furthermore, due to widespread use of antimicrobial agents in animal husbandry, it may be a selector for resistance, and $E$. coli strains can be rapidly spread among animals and transferred to humans [37]. Humans and animals are probably main reservoir of antimicrobial resistant E. coli, and their transmission can occur by direct contact or via food chain [24, 37]. Indeed, several studies found that the acquired antimicrobial resistance genes found in human E. coli isolates are closely associated to the genes found in animal isolates [24, 37].

Gut of a healthy individual is a probable reservoir of the microbial population carrying virulence and antimicrobial resistance related genes including the extended spectrum beta-lactamase (ESBL)-producing strains. A number of studies have been described about antimicrobial resistant commensal E. coli isolated from not only diseased patients [8, 17, 30, 43] but also healthy children and adults worldwide [2, 8, 14, 32]. Recently, much attention has been paid to ESBL-producing E. coli in healthy individuals as well $[1,4,5,15,21,22,32,42,44,47,50]$. In Vietnam, prevalence of antimicrobial resistance in commensal $E$. coli was

*Correspondence to: Yamasaki, S., Graduate School of Life and Environmental Sciences, Osaka Prefecture University, 1-58, Rinku orai-kita, Izumisano-shi, Osaka 598-8531, Japan. e-mail: shinji@vet.osakafu-u.ac.jp

(C2017 The Japanese Society of Veterinary Science

This is an open-access article distributed under the terms of the Creative Commons Attribution Non-Commercial No Derivatives (by-nc-nd) License. (CC-BY-NC-ND 4.0: https://creativecommons.org/licenses/by-nc-nd/4.o/) 
investigated in only children [14], raw food samples [49], household and small chicken farms [31]. However, comprehensive studies regarding analysis of antimicrobial resistance, ESBL type and virulence gene profile of commensal E. coli in adults were not conducted.

The study of the commensal E. coli population from healthy individuals is of great significance to understand and monitor the prevalence, distribution and carriage of pathogenic traits and antimicrobial resistance. The potentially pathogenic microbes with antimicrobial determinants may spread to other individuals not only from human but also animal and animal originated foods. On the other hand, the antimicrobial determinants may be transferred to more pathogenic bacteria in this niche. Keeping these factors in mind, this study was designed to characterize the commensal E. coli strains isolated from healthy adults of Ho Chi Minh City, Vietnam, for the presence of virulence gene, antimicrobial resistance profile and ESBL detection.

\section{MATERIALS AND METHODS}

\section{Bacterial isolates}

A total of 103 stool specimens were collected from healthy adults whose ages ranged from 20 to 70 years in 3 urban districts (73 adults in 3, 6 and Tan Phu) and 1 suburban district (30 adults in Cu Chi) in Ho Chi Minh City, Vietnam, during March to November 2013. It was confirmed that none of the study participants had history of taking antimicrobials at least 3 months before the sample collection. All people whose samples were collected gave their informed consent for the participation in this study. Stool specimens were inoculated onto CHROMagar Orientation (CHROMagar Paris France, Paris, France). After incubation at $37^{\circ} \mathrm{C}$ for $22 \pm 2 \mathrm{hr}$, a dark pink to reddish colony was selected and then identified to be E. coli by the IMViC tests [19]. One E. coli strain was collected from each sample and used for further analysis.

\section{Determination of antimicrobial susceptibility}

Antimicrobial susceptibility of the $E$. coli strains against ampicillin (AMP), cefotaxime (CTX), ceftazidime (CAZ), imipenem (IPM), nalidixic acid (NAL), ciprofloxacin (CIP), gentamicin (GEN), kanamycin (KAN), streptomycin (STR), fosfomycin (FOS), tetracycline (TET), trimethoprim/sulfamethoxazole (SXT) and chloramphenicol (CHL) was examined by disk diffusion method [11] on Mueller-Hinton agar (Becton Dickinson and Co., Sparks, NV, U.S.A.) using commercially available disks (Becton Dickinson and Co.). Charaterization of E. coli strains as susceptible, intermediate resistant or resistant was based on the size of the inhibition zones according to the Clinical and Laboratory Standards Institute (CLSI) guidelines [10]. E. coli strain ATCC 29522 was used as a control strain in the susceptibility test. MDR was defined as resistance to at least one antimicrobial agent in three or more classes of antimicrobial agents [6].

\section{ESBL phenotype and genotype confirmation}

ESBL phenotype was analyzed by a double-disk diffusion test using CTX, CAZ, CTX/clavulanic acid and CAZ/clavulanic acid [10]. ESBL ( $b l a_{\mathrm{CTX}-\mathrm{M}}, b l a_{\mathrm{TEM}}$ and $\left.b l a_{\mathrm{SHV}}\right)$ genes were determined by a multiplex PCR as described previously [27]. Genotype of bla $a_{\text {CTX-M }}$ genes was further analyzed by PCR using four primer sets targeting the CTX-M-1, CTX-M-2, CTX-M-8 and CTX-M-9 groups [40].

\section{Plasmid profile and location of bla ${ }_{C T X-M}$ gene}

Plasmid profiles of ESBL-producing E. coli strains were examined by S1-nuclease-PFGE with some modifications [3]. Briefly, a single genomic DNA block was incubated at $37^{\circ} \mathrm{C}$ for 40 min with 4 units of S1 nuclease (Thermo Fisher Scientific, Waltham, MA, U.S.A.) in $200 \mu \mathrm{l}$ of $30 \mathrm{mM}$ sodium acetate buffer ( $\mathrm{pH} 4.6$ ) including $50 \mathrm{mM} \mathrm{NaCl}, 1.0 \mathrm{mM}$ zinc acetate and $5 \%$ (v/v) glycerol. The digested DNA was electrophoresed on a 1.0\% pulsed-field certified agarose (Bio-Rad Laboratories Inc., Hercules, CA, U.S.A.) in $0.5 \mathrm{X}$ TBE (45 mM Tris, $45 \mathrm{mM}$ boric acid and $1 \mathrm{mM}$ EDTA) buffer at $6 \mathrm{~V} / \mathrm{cm}^{2}$, with a switch time of 2-60 sec for $21 \mathrm{hr}$ using the CHEF Mapper machine (Bio-Rad Laboratories Inc.). XbaI-digested Salmonella serotype Braenderup H98121 was used as a molecular size marker.

Location of bla $a_{\text {СТХ-M }}$ genes was analyzed by Southern hybridization. The resolved plasmids and genomic DNA by S1-PFGE gels were transferred onto nylon membranes (Perkin Elmer, Waltham, MA, U.S.A.). The membrane was hybridized with a specific ${ }^{32} \mathrm{P}-$ labeled DNA probe as described below. The $b l a_{\mathrm{CTX}-\mathrm{M}-1}$ and $b l a_{\mathrm{CTX}-\mathrm{M}-9}$ gene-probes were prepared by PCR using primers and conditions as described elsewhere [40] and labeled by random priming method using MultiPrime DNA Labeling System (GE Healthcare UK, Buckinghamshire, U.K.) with $\left[\alpha_{-}{ }^{32} \mathrm{P}\right]-\mathrm{dCTP}(111 \mathrm{TBq} / \mathrm{mmol})$ (Perkin Elmer). Radioactivity was visualized by the BAS FLA-3000 system (GE Healthcare, Tokyo, Japan).

\section{Phylogenetic characterization}

Phylogenetic group of E. coli strains was determined by using a multiplex PCR as reported previously [9].

\section{Detection of virulence genes for diarrheagenic E. coli}

A total of $103 \mathrm{E}$. coli strains were analyzed for the presence of virulence genes associated with diarrheagenic E. coli (DEC) including eae (E. coli-attaching and effacing), $b f p$ A (bundle-forming pilus), EAF (enteropathogenic E. coli adherence factor), elt (heat-labile enterotoxin), est (heat-stable enterotoxin), eagg (plasmid of enteroaggregative E. coli), astA (enteroaggregative E. coli heat-stable enterotoxin 1), stxl (Shiga toxin 1), stx2 (Shiga toxin 2), invE and daaD by colony hybridization assay using respective 
probe labeled with $\left[\alpha^{-32} \mathrm{P}\right]-\mathrm{dCTP}$ (Perkin Elmer) as described previously [36].

\section{RESULTS}

\section{Antimicrobial susceptibility}

A total of 103 E. coli strains including 73 from urban districts and 30 from suburban district were successfully isolated from 103 healthy adults in Ho Chi Minh City, Vietnam, and further analyzed for their antimicrobial susceptibility to 13 different drugs including AMP, CTX, CAZ, IPM, NAL, CIP, GEN, KAN, STR, FOS, TET, SXT and CHL. In this study, E. coli strains showing intermediate antimicrobial resistance were interpreted as resistant. As shown in Table 1, most of the E. coli strains were resistant to STR (80.6\%), TET (67.0\%), AMP (65.0\%), SXT (48.5\%) and NAL (43.7\%), although all E. coli strains were susceptible to IPM. Moreover, $96.1 \%$ of the $E$. coli strains (99/103) were resistant to one or more antimicrobial agents. Notably, MDR was detected in $71.8 \%(74 / 103)$ of the tested strains. In addition, extensive MDR, which was defined to be resistant against at least five different classes of antimicrobial agents, was detected in $41.7 \%(43 / 103)$ strains. There was no significant difference in rate of MDR of $E$. coli strains isolated from healthy adults in urban $(54 / 73 ; 74.0 \%)$ and suburban districts $(20 / 30 ; 66.7 \%)$.

\section{ESBL characterization and its genotype}

Since 51, 5 and 11 E. coli strains were resistant to AMP alone, AMP and CTX, AMP, CTX and CAZ, respectively, these strains might produce ESBL. Indeed, 10 out of the 67 strains were confirmed to be ESBL-producing E. coli. Among 10 ESBLproducing $E$. coli strains, 9 were isolated from healthy adults in urban districts, while 1 was from healthy adult in suburban district. Subsequently, ESBL genes were characterized for these 10 ESBL-producing $E$. coli strains, and the result is summarized in Table 2. The $b l a_{\mathrm{CTX}-\mathrm{M}}$ genes were detected in all the ESBL-producing E. coli. Moreover, five CTX-M-positive $E$. coli strains additionally possessed $b l a_{\mathrm{TEM}}$ genes, but none of the strains were positive for the $b l a_{\mathrm{SHV}}$ genes. Analysis of genotype for the $b l a_{\mathrm{CTX}-\mathrm{M}}$ genes

Table 1. Antimicrobial resistant E. coli strains isolated from healthy adults fecal samples $(\mathrm{n}=103)$

\begin{tabular}{|c|c|c|c|c|c|c|c|c|c|c|c|c|c|}
\hline & AMPa) $^{a}$ & $\mathrm{CTX}^{\mathrm{b})}$ & $\mathrm{CAZ}^{\mathrm{c})}$ & IPM $^{d)}$ & $\mathrm{NAL}^{\mathrm{e})}$ & CIPf) & GENg) & $\mathrm{KAN}^{\mathrm{h})}$ & STR $^{\mathrm{i})}$ & FOSi) & TET $^{\mathrm{k})}$ & $\mathrm{SXT}^{\mathrm{l})}$ & $\mathrm{CHL}^{\mathrm{m})}$ \\
\hline No. of isolates & 67 & 16 & 11 & 0 & 45 & 16 & 3 & 13 & 83 & 5 & 69 & 50 & 35 \\
\hline$\%$ & 65.0 & 15.5 & 10.7 & 0.0 & 43.7 & 15.5 & 2.9 & 12.6 & 80.6 & 4.9 & 67.0 & 48.5 & 34.0 \\
\hline
\end{tabular}

a) ampicillin, b) cefotaxime, c) ceftazidime, d) imipenem, e) nalidixic acid, f) ciprofloxacin, g) gentamicin, h) kanamycin, i) streptomycin, j) fosfomycin, k) tetracycline, 1) trimethoprim-sulphamethoxazole, m) chloramphenicol.

Table 2. Characteristics of $E$. coli strains, isolated from the fecal samples of healthy adults, carrying ESBL and/or virulence genes

\begin{tabular}{|c|c|c|c|c|c|c|}
\hline Isolate ID & Place & $\begin{array}{l}\text { Phylogenetic } \\
\text { group }\end{array}$ & $\begin{array}{c}\text { Virulence } \\
\text { gene }^{\text {a) }}\end{array}$ & Antimicrobial resistance phenotype & $\beta$-lactamase genes & $\begin{array}{c}\text { Location of } \\
\text { bla }_{\text {СТХ-M }}\end{array}$ \\
\hline E33 & District 3 & $\mathrm{~A}$ & $\mathrm{ND}^{\mathrm{b})}$ & AMP-CTX-CAZ & $b l a_{\mathrm{CTX}-\mathrm{M}-1}, b l a_{\mathrm{TEM}}$ & Plasmid \\
\hline E42 & Tan Phu & A & astA & AMP-CTX-NAL-TET-SXT & $b l a_{\mathrm{CTX}-\mathrm{M}-9}, b l a_{\mathrm{TEM}}$ & Chromosome \\
\hline E55 & Tan Phu & $\mathrm{D}$ & astA & AMP-CTX-NAL-SXT-STR & $b l a_{\mathrm{CTX}-\mathrm{M}-9}, b l a_{\mathrm{TEM}}$ & Plasmid \\
\hline E66 & Tan Phu & A & ND & AMP-CTX-CAZ-NAL-TET-SXT-STR-CHL & $b l a_{\mathrm{CTX}-\mathrm{M}-1}, b l a_{\mathrm{TEM}}$ & Plasmid \\
\hline E95 & District 6 & B1 & ND & AMP-CTX-CAZ-NAL-TET-SXT-CIP & $b l a_{\mathrm{CTX}-\mathrm{M}-1}, b l a_{\mathrm{TEM}}$ & Chromosome \\
\hline E96 & District 6 & $\mathrm{D}$ & ND & AMP-CTX-NAL-TET-SXT-STR-CHL-CIP & $b l a_{\text {CTX-M-9 }}$ & Chromosome \\
\hline E97 & District 6 & B1 & astA & AMP-CTX-NAL-KAN & $b l a_{\mathrm{CTX}-\mathrm{M}-9}$ & Plasmid \\
\hline E100 & District 6 & B1 & ast $A, \mathrm{EAF}$ & AMP-CTX-NAL-KAN & $b l a_{\mathrm{CTX}-\mathrm{M}-9}$ & Plasmid \\
\hline E101 & District 6 & B1 & ast $A, \mathrm{EAF}$ & AMP-CTX-NAL-KAN & $b l a_{\mathrm{CTX}-\mathrm{M}-9}$ & Plasmid \\
\hline E137 & $\mathrm{Cu}$ Chi & $\mathrm{B} 2$ & ND & AMP-CTX-NAL-TET-SXT-STR-CIP & $b l a_{\mathrm{CTX}-\mathrm{M}-9}$ & Plasmid \\
\hline E21 & District 3 & A & astA & NAL & $\mathrm{NA}^{\mathrm{c})}$ & NA \\
\hline E23.13 & District 3 & B1 & astA & AMP-CHL-SXT & NA & NA \\
\hline E25.13 & District 3 & A & astA & AMP-CHL-CIP-FOS-GEN-KAN-NAL-STR-TET-SXT & NA & NA \\
\hline E35.13 & Tan Phu & A & ast $A$, elt & CHL-KAN-STR-TET-SXT & NA & NA \\
\hline E41.13 & Tan Phu & $\mathrm{D}$ & ast $A$, eaeA & AMP-CTX-CAZ-CIP-NAL-STR-TET & NA & NA \\
\hline E48.13 & Tan Phu & B1 & EAF, eagg & AMP-STR-TET & NA & NA \\
\hline E62.13 & Tan Phu & A & astA & FOS-STR & NA & NA \\
\hline E63.13 & Tan Phu & A & ast A, eagg & AMP-STR-TET-SXT & NA & NA \\
\hline E64.13 & Tan Phu & A & EAF & AMP-CHL-FOS-STR-TET-SXT & NA & NA \\
\hline E65.13 & Tan Phu & A & EAF & KAN-NAL-TET & NA & NA \\
\hline E135.13 & $\mathrm{Cu}$ Chi & B1 & ast $A$, elt & STR & NA & NA \\
\hline E136.13 & District 3 & $\mathrm{D}$ & ast $A$, elt & AMP-CHL-STR-TET-SXT & NA & NA \\
\hline E153.13 & $\mathrm{Cu}$ Chi & B1 & astA & AMP-CHL-CIP-KAN-NAL-STR-TET-SXT & NA & NA \\
\hline
\end{tabular}

a) eaeA (E. coli-attaching and effacing), EAF (enteropathogenic E. coli adherence factor), elt (heat-labile enterotoxin), eagg (plasmid of enteroaggregative E. coli), astA (enteroaggregative stable enterotoxin). b) not detected, c) not applicable. 
exhibited that most of the $E$. coli strains belonged to $b l a_{\mathrm{CTX}-\mathrm{M}-9}$ group (70.0\%), followed by bla $a_{\mathrm{CTX}-\mathrm{M}-1}$ group (30.0\%).

\section{Plasmid profiles and location of bla ${ }_{C T X-M}$ genes}

In general, the ESBL genes are predominantly located on plasmids and are easily disseminated. To see if ESBL genes are located on plasmid or chromosome, plasmid profile and location of bla ${ }_{\mathrm{CTX}-\mathrm{M}}$ genes were analyzed for the 10 ESBL-producing $E$. coli strains by PFGE with S1-nuclease digestion and Southern hybridization. As shown in Fig. 1, there was at least one large plasmid ranging from 50 to $244 \mathrm{~kb}$ in size and a variation of plasmid profiles in ESBL-producing E. coli.

The Southern hybridization of S1-PFGE gel demonstrated that most of the ESBL-producing E. coli (7/10 isolates) harbored the $b l a_{\mathrm{CTX}-\mathrm{M}}$ genes on a large plasmid (ranging from 50 to $200 \mathrm{~kb}$ in size) as shown in Fig. 1. Other 3 strains, however, carried the $b l a_{\mathrm{CTX}-\mathrm{M}}$ genes on chromosome. Moreover, among the 5 strains harboring both $b l a_{\mathrm{CTX}-\mathrm{M}}$ and $b l a_{\mathrm{TEM}}$ genes, 3 strains carried these genes on the same plasmid (data not shown).

\section{Phylogenetic characterization}

We further examined the 103 E. coli strains for phylogenetic group. The majority of the E. coli strains isolated from healthy humans belonged to phylogenetic group A (44.7\%) followed by B1 (23.3\%), B2 (18.4\%) and D (13.6\%) groups (data not shown). Moreover, the highest prevalence of $E$. coli strains showing MDR was distributed into the phylogenetic group A (34/74, 45.9\%), followed by groups B1 (16/74, 21.6\%), B2 (13/74, 17.6\%) and D (11/74, 14.9\%). Most ESBL-producing E. coli strains belonged to phylogenetic groups A $(3 / 10,30 \%)$ and B1 $(4 / 10 ; 40 \%)$.

\section{Virulence gene profile}

Distribution of virulence genes associated with DEC was examined, and the result is shown in Table 2. Of 103 E. coli strains, none of the strains were positive for $b f p A$, est, stx $1, s t x 2$, invE and daaD genes. However, ast $A$ was most prevalent and detected in 15 strains, followed by EAF $(\mathrm{n}=5)$, elt $(\mathrm{n}=3)$, eagg $(\mathrm{n}=2)$ and eae $(\mathrm{n}=1)$, indicating that some of the E. coli strains isolated from healthy adults are potentially virulent to human. In addition, 7 ast $A$ genes were detected in combination with EAF ( $\mathrm{n}=2)$, elt $(\mathrm{n}=3)$, eagg $(\mathrm{n}=1)$ and eae $\mathrm{(n=1)}$. Fifteen out of $18 \mathrm{E}$. coli strains harboring virulence genes were MDR. Thus, the strains carrying both virulence and antimicrobial resistance genes may pose a serious threat to public health. Besides, 8,7 and 3 E. coli strains harboring virulence genes belonged to the phylogenetic groups A, B1 and D, respectively (Table 2). Furthermore, 2 out of these 18 E. coli strains harboring virulence genes were isolated from healthy adults in suburban districts.

\section{DISCUSSION}

Emergence of antimicrobial resistant bacteria has been increasingly recognized as a serious problem in the world. Recently, a number of studies regarding prevalence of antimicrobial resistant $E$. coli including ESBL producer in not only hospitalized patients but also healthy people have been reported in many parts of the world [1, 4, 15, 21-23, 32, 42, 47]. However, there was less report regarding the comprehensive analysis of antimicrobial resistant E. coli strains isolated from healthy children in Vietnam [14].

In the present study, therefore, we attempted to isolate $E$. coli from healthy adults in Ho Chi Minh City in Vietnam for further characterization of their antimicrobial resistance, ESBL genotype and its location, phylogenetic groups and virulence gene profiles. A total of $103 \mathrm{E}$. coli were successfully isolated, and most of the strains showed resistance to one or more antimicrobials. The results of antimicrobial susceptibility in this study are in accordance with a previous study of healthy children in FilaBavi, near Hanoi, Vietnam, except for CIP [14] in which only 6 antimicrobials, such as AMP, CIP, CHL, NAL, TET, and SXT were examined and the isolated E. coli strains were resistant to AMP (65\%), TET (74\%), CHL (40\%), NAL (27\%) and SXT (68\%). However, $<1 \%$ of the E. coli strains isolated in FilaBavi were resistant to CIP [14], although $15.5 \%$ strains were resistant to CIP in this study. Surprisingly, $72 \%$ of the $E$. coli strains were MDR, and furthermore, $42 \%$ of the E. coli strains were extensive MDR. This high rate of MDR was observed in the E. coli strains isolated from healthy adults in both urban and suburban districts in Ho Chi Minh City. These percentages are quite high in comparison to those observed in a French study [32], but consistent with those reported from Korea and Bolivia $[2,8]$. These results revealed a high risk of fecal carriage of antimicrobial resistant $E$. coli strains in healthy adults in Ho Chi Minh City, Vietnam. One reason could be due to improper use of antimicrobials for human in Vietnam where antimicrobials can be purchased over the counter without a prescription and there is no sanction for non-compliance of drug law regulations [28]. Alternatively, it could be due to improper use of antimicrobials for food-animals [7, 48] and veterinary medicine. The phenomenon of over usage of antimicrobials and thus emergence of MDR is an emerging problem worldwide, especially in developing countries. It could be also possible that antimicrobial resistant $E$. coli might be transmitted from food-animals and raw foods to human. The previous studies from southern Vietnam suggested that food-animals and raw foods could be a potential reservoir of antimicrobial resistance bacteria that disseminated to human [31, 49]. It was found that commensal E. coli isolates on household and small-scale chicken farms in the Mekong Delta of Vietnam have high prevalence of resistance to TET, AMP, SXT, and CHL ( $>60 \%)$ and MDR (81.3\%), indicating the high risk of transmission of antimicrobial-resistant E. coli to community [31]. It was also reported that $61.6 \%$ of $E$. coli isolates from raw foods in the marketplace in Ho Chi Minh City were MDR and some of the tested strains contained a pool of mobile genetic elements for dissemination of antimicrobial resistant genes to human [49]. The occurrence rate of ESBL-producing E. coli in this study was lower than that of community from Hanoi, Vietnam (46.7\%) [46], Thailand (65.7\%) [23] and China (50.5\%) [21], but consistent with that of community in Libya (13.4\%) [1], Tunisia (7.3\%) [4], Japan (6.4\%) [22], Germany (6.3\%) [47], France (6.0\%) [32], Netherlands (7.8\%) [42] and Switzerland (5.8\%) [15]. Higher 


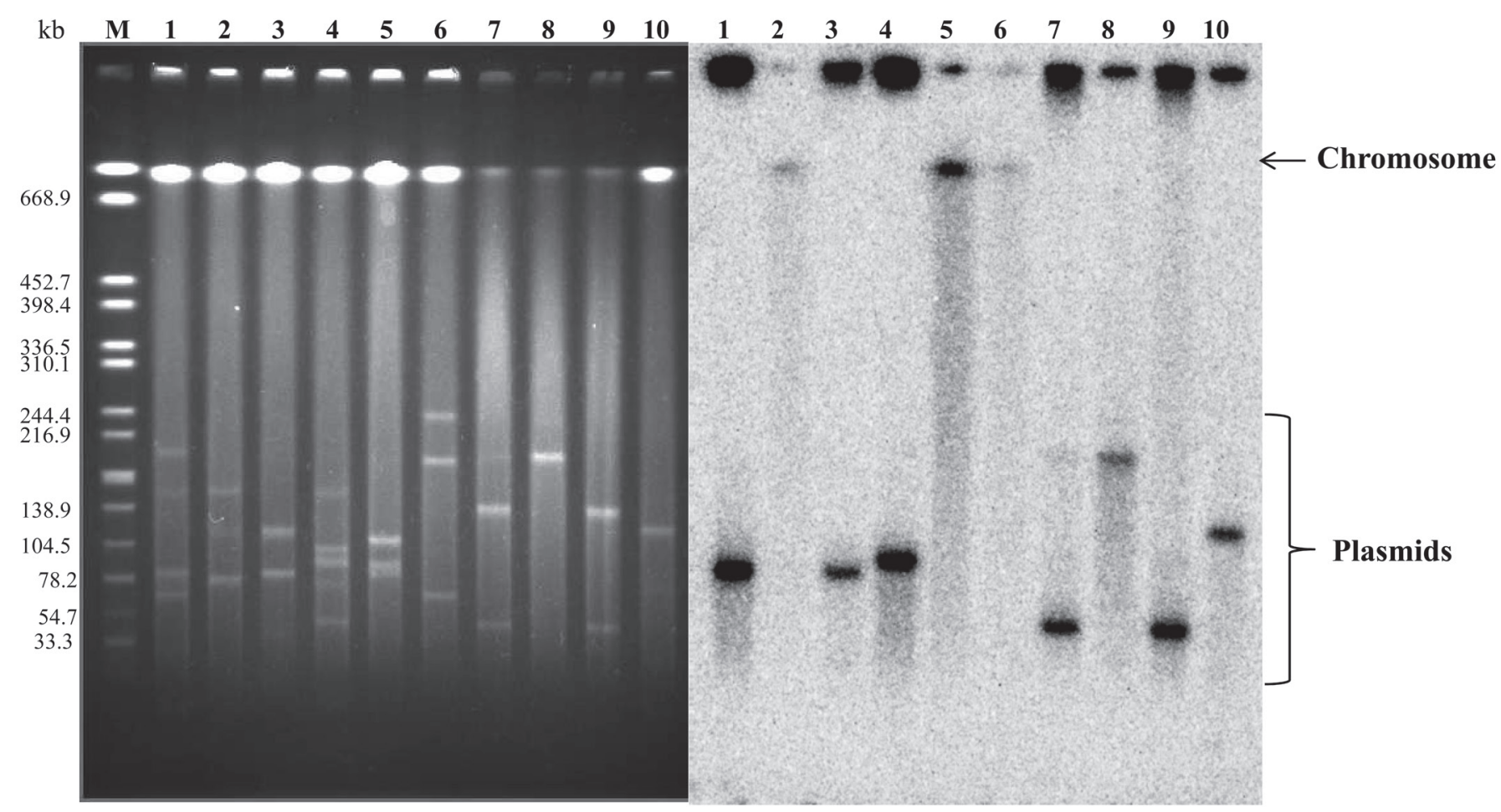

Fig. 1. Location of the bla genes in ESBL-producing E. coli strains isolated from fecal samples of healthy humans. Left panel; Separation of S1 nuclease-digested DNAs by PFGE. Right panel; Southern hybridization with a bla $a_{\mathrm{CTX}-\mathrm{M}}$ gene-probe. Lanes: 1, E. coli strain E33; 2, E42; 3, E55; 4, E66; 5, E95; 6, E96; 7, E97; 8, E100; 9, E101; 10, E137. M, XbaI-digested DNA from S. enterica serotype Braenderup strain H9812 used as molecular size markers.

prevalence of ESBL-producing E. coli in Hanoi, Vietnam, and other countries could be due to differences in the isolation protocols. In those studies, $\beta$-lactam supplemented agar media were used for the isolation of the E. coli. ESBLs can be broadly divided into three groups, such as TEM, SHV and CTX-M, and CTX-M $\beta$-lactamases are the most widespread and frequently detected in E. coli [39]. In addition, genotype of CTX-Ms was found to be different and specific between regions in the world [50]. In this study, $b l a_{\text {CTX-M-9 }}$ was found to be the most predominant group in healthy adults in Ho Chi Minh City, which is similar in northern Vietnam [5], Thailand [23] and China [21]. Whereas bla $a_{\mathrm{CTX}-\mathrm{M}-1}$ group was the most predominant $\beta$-lactamase gene in ESBLproducing E. coli in healthy carriage in European countries, such as Germany, France, Netherland and Switzerland [15, 32, 42, 47]. In Ho Chi Minh City, it has been reported that $b l a_{\mathrm{CTX-M-9}}$ and $b l a_{\mathrm{CTX-M-1}}$ groups were the two most predominant types among ESBL-producing E. coli strains from foods [29] and patients with nosocomial infections in hospitals [45]. These data suggest that $b l a_{\mathrm{CTX-М-9}}$ and $b l a_{\text {СтХ-М-1 }}$ groups might be circulating among foods, healthy adults and clinical settings in Ho Chi Minh City, Vietnam.

It is well known that plasmid plays an important role in the horizontal transfer of antimicrobial resistant genes in microbes including ESBL $[12,25]$. In this study, bla $_{\mathrm{CTX}-\mathrm{M}}$ genes were detected on plasmids, whose sizes are ranged from about 50 to 200 $\mathrm{kb}$, in 7 out of 10 ESBL-producing E. coli strains. Our data indicate that ESBL-producing E. coli in healthy carriage could be a potential reservoir and source of dissemination of plasmid-mediated ESBL genes.

Phylogenetic group of $E$. coli strains isolated from healthy adults was investigated. It has been reported that the intestinal pathogenic E. coli are mostly classified into phylogenetic groups A, B1 and D [41], whereas strains belonging to phylogenetic group B2 are highly virulent and associated with extra-intestinal infections [38]. Most of the E. coli strains isolated in this study were identified to be phylogenetic group A followed by groups B1, B2 and D. This result is consistent with many of the previous reports that $E$. coli from community mainly belonged to phylogenetic group A [9, 47]. Notably, the majority of MDR $E$. coli strains in this study belonged to phylogenetic group A (34/74 strains). Furthermore, 13 of the MDR E. coli strains belonged to phylogenetic group B2, suggesting that these strains might have a potential virulence capacity and could pose a risk to public health.

Furthermore, virulence gene profile analysis indicated that indeed 18 E. coli strains carried one or two virulence genes associated with DEC (Table 2). Among 11 virulence genes tested, ast $A$ was most prevalent, and some of the strains carried eae, EAF, elt and eagg in addition to astA. astA encoding EAST1 was initially detected in enteroaggregative E. coli (EAEC) [26] and thought to be a specific virulence factor of EAEC. However, ast A has been detected in E. coli strains belonging to various pathotypes [41], and significance of EAST1 in diarrhea is not still clear. On the other hand, there are several reports regarding association of $E$. coli containing only ast $A$ among various virulence genes for DEC with a few outbreaks all over the world [16, 33, 34, 51], indicating 
MDR E. coli having DEC-associated virulence genes, in particular astA-positive MDR E. coli strains, might be harmful to human.

In conclusion, most of the $E$. coli strains isolated from healthy adults in Ho Chi Minh City, Vietnam, are MDR including extensive MDR. Some of them have virulence genes associated with DEC. Together with phylogenetic analysis, these data suggest that $E$. coli strains in healthy adults in southern Vietnam could be reservoir of antimicrobial resistance genes including ESBL and might be harmful to human.

ACKNOWLEDGMENTS. We thank Dr. Rupak K. Bhadra (CSIR-Indian Institute of Chemical Biology, Kolkata, India) for the critical reading of the manuscript. This study was performed in partial fulfillment of the requirements of a PhD thesis for Hoang Hoai Phuong from Graduate School of Life and Environmental Sciences, Osaka Prefecture University, Osaka, Japan. This work was supported by the Japan Agency for Medical Research and Development (AMED)/Japan International Cooperation Agency (JICA) as part of the Science and Technology Research Partnership for Sustainable Development (SATREPS).

\section{REFERENCES}

1. Ahmed, S. F., Ali, M. M. M., Mohamed, Z. K., Moussa, T. A. and Klena, J. D. 2014. Fecal carriage of extended-spectrum $\beta$-lactamases and AmpCproducing Escherichia coli in a Libyan community. Ann. Clin. Microbiol. Antimicrob. 13: 22. [Medline] [CrossRef]

2. Bartoloni, A., Bartalesi, F., Mantella, A., Dell'Amico, E., Roselli, M., Strohmeyer, M., Barahona, H. G., Barrón, V. P., Paradisi, F. and Rossolini, G. M. 2004. High prevalence of acquired antimicrobial resistance unrelated to heavy antimicrobial consumption. J. Infect. Dis. 189: 1291-1294. [Medline] [CrossRef]

3. Barton, B. M., Harding, G. P. and Zuccarelli, A. J. 1995. A general method for detecting and sizing large plasmids. Anal. Biochem. 226: 235-240. [Medline] [CrossRef]

4. Ben Sallem, R., Ben Slama, K., Estepa, V., Jouini, A., Gharsa, H., Klibi, N., Sáenz, Y., Ruiz-Larrea, F., Boudabous, A. and Torres, C. 2012. Prevalence and characterisation of extended-spectrum beta-lactamase (ESBL)-producing Escherichia coli isolates in healthy volunteers in Tunisia. Eur. J. Clin. Microbiol. Infect. Dis. 31: 1511-1516. [Medline] [CrossRef]

5. Bui, T. M. H., Hirai, I., Ueda, S., Bui, T. K. N., Hamamoto, K., Toyosato, T., Le, D. T. and Yamamoto, Y. 2015. Carriage of Escherichia coli producing CTX-M-Type extended-spectrum $\beta$-lactamase in healthy vietnamese individuals. Antimicrob. Agents Chemother. 59: 6611-6614. [Medline] [CrossRef]

6. Cantón, R. and Ruiz-Garbajosa, P. 2011. Co-resistance: an opportunity for the bacteria and resistance genes. Curr. Opin. Pharmacol. 11: 477-485. [Medline] [CrossRef]

7. Carrique-Mas, J. J., Trung, N. V., Hoa, N. T., Mai, H. H., Thanh, T. H., Campbell, J. I., Wagenaar, J. A., Hardon, A., Hieu, T. Q. and Schultsz, C. 2015. Antimicrobial usage in chicken production in the Mekong Delta of Vietnam. Zoonoses Public Health 62 Suppl 1: 70-78. [Medline] [CrossRef]

8. Cho, S. H., Lim, Y. S., Park, M. S., Kim, S. H. and Kang, Y. H. 2011. Prevalence of antibiotic resistance in Escherichia coli fecal isolates from healthy persons and patients with diarrhea. Osong Public Health Res. Perspect. 2: 41-45. [Medline] [CrossRef]

9. Clermont, O., Bonacorsi, S. and Bingen, E. 2000. Rapid and simple determination of the Escherichia coli phylogenetic group. Appl. Environ. Microbiol. 66: 4555-4558. [Medline] [CrossRef]

10. CLSI 2014. Performance standards for antimicrobial susceptibility testing. Twenty-Fourth Informational (Supplement): M100-S24 Wayne, PA, U.S.A.

11. CLSI 2012. Methods for dilution antimicrobial susceptibility tests for bacteria that grow aerobically; Approved standard-ninth edition M7-A9. Wayne, PA, U.S.A.

12. D’Andrea, M. M., Arena, F., Pallecchi, L. and Rossolini, G. M. 2013. CTX-M-type $\beta$-lactamases: a successful story of antibiotic resistance. Int. J. Med. Microbiol. 303: 305-317. [Medline] [CrossRef]

13. Donnenberg, M. S. and Whittam, T. S. 2001. Pathogenesis and evolution of virulence in enteropathogenic and enterohemorrhagic Escherichia coli. J. Clin. Invest. 107: 539-548. [Medline] [CrossRef]

14. Dyar, O. J., Hoa, N. Q., Trung, N. V., Phuc, H. D., Larsson, M., Chuc, N. T. K. and Lundborg, C. S. 2012. High prevalence of antibiotic resistance in commensal Escherichia coli among children in rural Vietnam. BMC Infect. Dis. 12: 92. [Medline] [CrossRef]

15. Geser, N., Stephan, R., Korczak, B. M., Beutin, L. and Hächler, H. 2012. Molecular identification of extended-spectrum- $\beta$-lactamase genes from Enterobacteriaceae isolated from healthy human carriers in Switzerland. Antimicrob. Agents Chemother. 56: 1609-1612. [Medline] [CrossRef]

16. Hedberg, C. W., Savarino, S. J., Besser, J. M., Paulus, C. J., Thelen, V. M., Myers, L. J., Cameron, D. N., Barrett, T. J., Kaper, J. B. and Osterholm, M. T. 1997. An outbreak of foodborne illness caused by Escherichia coli O39:NM, an agent not fitting into the existing scheme for classifying diarrheogenic E. coli. J. Infect. Dis. 176: 1625-1628. [Medline] [CrossRef]

17. Jafari, F., Hamidian, M., Rezadehbashi, M., Doyle, M., Salmanzadeh-Ahrabi, S., Derakhshan, F. and Reza Zali, M. 2009. Prevalence and antimicrobial resistance of diarrheagenic Escherichia coli and Shigella species associated with acute diarrhea in Tehran, Iran. Can. J. Infect. Dis. Med. Microbiol. 20: e56-e62. [Medline]

18. Kaper, J. B., Nataro, J. P. and Mobley, H. L. 2004. Pathogenic Escherichia coli. Nat. Rev. Microbiol. 2: 123-140. [Medline] [CrossRef]

19. Kodaka, H., Mizuochi, S., Teramura, H. and Nirazuka, T. 2006. Comparison of the compact dry EC with the most probable number method (AOAC official method 966.24) for enumeration of Escherichia coli and coliform bacteria in raw meats. Performance-Tested Method 110402. J. AOAC Int. 89: 100-114. [Medline]

20. Levy, S. B. and Marshall, B. 2004. Antibacterial resistance worldwide: causes, challenges and responses. Nat. Med. 10 Suppl: S122-S129. [Medline] [CrossRef]

21. Li, B., Sun, J. Y., Liu, Q. Z., Han, L. Z., Huang, X. H. and Ni, Y. X. 2011. High prevalence of CTX-M $\beta$-lactamases in faecal Escherichia coli strains from healthy humans in Fuzhou, China. Scand. J. Infect. Dis. 43: 170-174. [Medline] [CrossRef]

22. Luvsansharav, U. O., Hirai, I., Niki, M., Nakata, A., Yoshinaga, A., Moriyama, T. and Yamamoto, Y. 2011. Prevalence of fecal carriage of extendedspectrum $\beta$-lactamase-producing Enterobacteriaceae among healthy adult people in Japan. J. Infect. Chemother. 17: 722-725. [Medline] [CrossRef]

23. Luvsansharav, U. O., Hirai, I., Nakata, A., Imura, K., Yamauchi, K., Niki, M., Komalamisra, C., Kusolsuk, T. and Yamamoto, Y. 2012. Prevalence of and risk factors associated with faecal carriage of CTX-M $\beta$-lactamase-producing Enterobacteriaceae in rural Thai communities. J. Antimicrob. 
Chemother. 67: 1769-1774. [Medline] [CrossRef]

24. Marshall, B. M. and Levy, S. B. 2011. Food animals and antimicrobials: impacts on human health. Clin. Microbiol. Rev. 24: 718-733. [Medline] [CrossRef]

25. Mathers, A. J., Peirano, G. and Pitout, J. D. D. 2015. The role of epidemic resistance plasmids and international high-risk clones in the spread of multidrug-resistant Enterobacteriaceae. Clin. Microbiol. Rev. 28: 565-591. [Medline] [CrossRef]

26. Ménard, L. P. and Dubreuil, J. D. 2002. Enteroaggregative Escherichia coli heat-stable enterotoxin 1 (EAST1): a new toxin with an old twist. Crit. Rev. Microbiol. 28: 43-60. [Medline] [CrossRef]

27. Monstein, H. J., Ostholm-Balkhed, A., Nilsson, M. V., Nilsson, M., Dornbusch, K. and Nilsson, L. E. 2007. Multiplex PCR amplification assay for the detection of blaSHV, blaTEM and blaCTX-M genes in Enterobacteriaceae. APMIS 115: 1400-1408. [Medline] [CrossRef]

28. Nga, T. T., Chuc, N. T. K., Hoa, N. P., Hoa, N. Q., Nguyen, N. T. T., Loan, H. T., Toan, T. K., Phuc, H. D., Horby, P., Van Yen, N., Van Kinh, N. and Wertheim, H. F. L. 2014. Antibiotic sales in rural and urban pharmacies in northern Vietnam: an observational study. BMC Pharmacol. Toxicol. 15: 6. [Medline] [CrossRef]

29. Nguyen do P., Nguyen, T. A., Le, T. H., Tran, N. M., Ngo, T. P., Dang, V. C., Kawai, T., Kanki, M., Kawahara, R., Jinnai, M., Yonogi, S., Hirai, Y., Yamamoto, Y. and Kumeda, Y. 2016. Dissemination of extended-spectrum beta-Lactamase- and AmpC beta-Lactamase-Producing Escherichia coli within the food distribution system of Ho Chi Minh City, Vietnam. Biomed. Res. Int. 2016: 8182096.

30. Nguyen, T. V., Le, P. V., Le, C. H. and Weintraub, A. 2005. Antibiotic resistance in diarrheagenic Escherichia coli and Shigella strains isolated from children in Hanoi, Vietnam. Antimicrob. Agents Chemother. 49: 816-819. [Medline] [CrossRef]

31. Nguyen, V. T., Carrique-Mas, J. J., Ngo, T. H., Ho, H. M., Ha, T. T., Campbell, J. I., Nguyen, T. N., Hoang, N. N., Pham, V. M., Wagenaar, J. A., Hardon, A., Thai, Q. H. and Schultsz, C. 2015. Prevalence and risk factors for carriage of antimicrobial-resistant Escherichia coli on household and small-scale chicken farms in the Mekong Delta of Vietnam. J. Antimicrob. Chemother. 70: 2144-2152. [Medline]

32. Nicolas-Chanoine, M. H., Gruson, C., Bialek-Davenet, S., Bertrand, X., Thomas-Jean, F., Bert, F., Moyat, M., Meiller, E., Marcon, E., Danchin, N., Noussair, L., Moreau, R. and Leflon-Guibout, V. 2013. 10-Fold increase (2006-11) in the rate of healthy subjects with extended-spectrum $\beta$-lactamase-producing Escherichia coli faecal carriage in a Parisian check-up centre. J. Antimicrob. Chemother. 68: 562-568. [Medline] [CrossRef]

33. Nishikawa, Y., Ogasawara, J., Helander, A. and Haruki, K. 1999. An outbreak of gastroenteritis in Japan due to Escherichia coli O166. Emerg. Infect. Dis. 5: 300. [Medline] [CrossRef]

34. Nishikawa, Y., Zhou, Z., Hase, A., Ogasawara, J., Kitase, T., Abe, N., Nakamura, H., Wada, T., Ishii, E., Haruki K., Surveillance Team 2002. Diarrheagenic Escherichia coli isolated from stools of sporadic cases of diarrheal illness in Osaka City, Japan between 1997 and 2000: prevalence of enteroaggregative E. coli heat-stable enterotoxin 1 gene-possessing E. coli. Jpn. J. Infect. Dis. 55: 183-190. [Medline]

35. Okeke, I. N., Aboderin, O. A., Byarugaba, D. K., Ojo, K. K. and Opintan, J. A. 2007. Growing problem of multidrug-resistant enteric pathogens in Africa. Emerg. Infect. Dis. 13: 1640-1646. [Medline] [CrossRef]

36. Ombarak, R. A., Hinenoya, A., Awasthi, S. P., Iguchi, A., Shima, A., Elbagory, A. R. M. and Yamasaki, S. 2016. Prevalence and pathogenic potential of Escherichia coli isolates from raw milk and raw milk cheese in Egypt. Int. J. Food Microbiol. 221: 69-76. [Medline] [CrossRef]

37. Perreten, V. 2005, Frontiers in Antimicrobial Resistance. American Society of Microbiology.

38. Picard, B., Garcia, J. S., Gouriou, S., Duriez, P., Brahimi, N., Bingen, E., Elion, J. and Denamur, E. 1999. The link between phylogeny and virulence in Escherichia coli extraintestinal infection. Infect. Immun. 67: 546-553. [Medline]

39. Pitout, J. D. and Laupland, K. B. 2008. Extended-spectrum beta-lactamase-producing Enterobacteriaceae: an emerging public-health concern. Lancet Infect. Dis. 8: 159-166. [Medline] [CrossRef]

40. Pitout, J. D., Hossain, A. and Hanson, N. D. 2004. Phenotypic and molecular detection of CTX-M-beta-lactamases produced by Escherichia coli and Klebsiella spp. J. Clin. Microbiol. 42: 5715-5721. [Medline] [CrossRef]

41. Pupo, G. M., Karaolis, D. K., Lan, R. and Reeves, P. R. 1997. Evolutionary relationships among pathogenic and nonpathogenic Escherichia coli strains inferred from multilocus enzyme electrophoresis and mdh sequence studies. Infect. Immun. 65: 2685-2692. [Medline]

42. Reuland, E. A., Al Naiemi, N., Kaiser, A. M., Heck, M., Kluytmans, J. A., Savelkoul, P. H., Elders, P. J. and Vandenbroucke-Grauls, C. M. 2016. Prevalence and risk factors for carriage of ESBL-producing Enterobacteriaceae in Amsterdam. J. Antimicrob. Chemother. 71: 1076-1082. [Medline] [CrossRef]

43. Sabir, S., Ahmad Anjum, A., Ijaz, T., Asad Ali, M., Ur Rehman Khan, M. and Nawaz, M. 2014. Isolation and antibiotic susceptibility of E. coli from urinary tract infections in a tertiary care hospital. Pak. J. Med. Sci. 30: 389-392. [Medline]

44. Sasaki, T., Hirai, I., Niki, M., Nakamura, T., Komalamisra, C., Maipanich, W., Kusolsuk, T., Sa-Nguankiat, S., Pubampen, S. and Yamamoto, Y. 2010. High prevalence of CTX-M $\beta$-lactamase-producing Enterobacteriaceae in stool specimens obtained from healthy individuals in Thailand. $J$. Antimicrob. Chemother. 65: 666-668. [Medline] [CrossRef]

45. Trang, N. H., Nga, T. V., Campbell, J. I., Hiep, N. T., Farrar, J., Baker, S. and Duy, P. T. 2013. The characterization of ESBL genes in Escherichia coli and Klebsiella pneumoniae causing nosocomial infections in Vietnam. J. Infect. Dev. Ctries. 7: 922-928. [Medline] [CrossRef]

46. Ueda, S., Ngan, B. T. K., Huong, B. T. M., Hirai, I., Tuyen, D. and Yamamoto, Y. 2015. Limited transmission of bla(CTX-M-9)-type-positive Escherichia coli between humans and poultry in Vietnam. Antimicrob. Agents Chemother. 59: 3574-3577. [Medline] [CrossRef]

47. Valenza, G., Nickel, S., Pfeifer, Y., Eller, C., Krupa, E., Lehner-Reindl, V. and Höller, C. 2014. Extended-spectrum- $\beta$-lactamase-producing Escherichia coli as intestinal colonizers in the German community. Antimicrob. Agents Chemother. 58: 1228-1230. [Medline] [CrossRef]

48. Van Cuong, N., Nhung, N. T., Nghia, N. H., Mai Hoa, N. T., Trung, N. V., Thwaites, G. and Carrique-Mas, J. 2016. Antimicrobial consumption in medicated feeds in vietnamese pig and poultry production. EcoHealth 13: 490-498. [Medline] [CrossRef]

49. Van, T. T. H., Moutafis, G., Tran, L. T. and Coloe, P. J. 2007. Antibiotic resistance in food-borne bacterial contaminants in Vietnam. Appl. Environ. Microbiol. 73: 7906-7911. [Medline] [CrossRef]

50. Woerther, P. L., Burdet, C., Chachaty, E. and Andremont, A. 2013. Trends in human fecal carriage of extended-spectrum $\beta$-lactamases in the community: toward the globalization of CTX-M. Clin. Microbiol. Rev. 26: 744-758. [Medline] [CrossRef]

51. Zhou, Z., Ogasawara, J., Nishikawa, Y., Seto, Y., Helander, A., Hase, A., Iritani, N., Nakamura, H., Arikawa, K., Kai, A., Kamata, Y., Hoshi, H. and Haruki, K. 2002. An outbreak of gastroenteritis in Osaka, Japan due to Escherichia coli serogroup O166:H15 that had a coding gene for enteroaggregative E. coli heat-stable enterotoxin 1 (EAST1). Epidemiol. Infect. 128: 363-371. [Medline] [CrossRef] 